\title{
Uncovering Teachers Perceptions on the Incorporation of Multicultural Picture Books in the Secondary Classroom
}

\author{
Torri S. Bryant, Tami B Morton \\ Texas A \& M University-Commerce, Texas, United States
}

\begin{abstract}
The contemporary multicultural picture book is an essential tool used to enrich curriculum in classrooms across the United States. As teachers expose their students to the story, the text becomes the catalyst to perceiving the literature as a mirror into their own culture, a window or a sliding door into other cultures. All of these perspectives are needed to educate students in our multicultural society. The purpose of this study is to provoke thought in teachers before they select contemporary multicultural pictures books to enrich their classrooms. This choice should not be based only on their thoughts about the cover, title or illustrations; but teachers should also consider the impact the main character's agency can have on their students' cultural perceptions of themselves and others. This article reflects the learning from the study through the eyes of the educator (doctoral student) and her professor.
\end{abstract}

\section{Introduction}

Each year classrooms embrace students from different races, religions, and regions from around the world. Valuing their cultures, and personalities, is something that educators teach, model, and practice in their classrooms; but it is not always reflected in the literature that we bring to share with the students. Some books show main characters from different cultures as heroes, those that can solve their own problems; while others show them as victims, those who need help solving their own problems. "When children cannot find themselves reflected in the books they read, or when the images they see are distorted, negative, or laughable, they learn a powerful lesson about how they are devalued in the society of which they are a part. Our classrooms need to be a place where all the children from all the cultures that make up the salad bowl of American society can find their mirrors [17]."

As a secondary educator, I (Torri) have always had an affinity for good books. I have effectively been able to connect with my adolescent students through the use of a relatable story, with all of the story elements, text styles, and perspectives mandated by our curriculum to cover during the school year. However, it was in a recent graduate class that I realized multicultural picture books can provide much more than responses to "right there" questions for students, they can also provide an avenue to encourage a more encompassing view of culture and society; one in which they are accepted and encouraged to thrive without losing their own cultural identity.

Through my graduate course, I was challenged to use another perspective to consider when evaluating texts for my classroom, a pluralistic view. Torri spoke to her professor, Tami, who was eager to discuss the different perspectives teachers use when sharing adolescent and children's literature in their classrooms. In this class, many of the books focused on different cultures rather than those traditionally used in the classroom, including Refugee (Gratz, 2018), The 57 Bus (Slater, 2018), and Long Way Down (Reynolds, 2018).

The text that the teacher choses to expose their students to become the lenses in which the students will perceive various people, and cultures, in their daily lives. In Dallas Fort Worth metroplex, $44 \%$ of the population is made up of New Americans. In addition to the large number of new people, there are 239 languages spoken in the DFW area (DFW Alliance, 2014). Dallas is one of the most populated areas in the state, the $2^{\text {nd }}$ largest state in the nation. According to the 2010 census, Hispanic people make up $37.6 \%$ of the population in Texas with a great possibility of growing to a percentage higher than the majority by 2020 [3]. These numbers can't be ignored.

The purpose of this study is to bring awareness to teachers on how multicultural picture books represent people of various cultures; and to provoke thought for the selection of the book before using them as instructional tools to enrich the curriculum in their classrooms.

\section{Research Questions}

In order to address my topic and provide direction to this study, it is important to generate research questions. What follows is the main question and 
several sub-questions that were produced to drive the study.

Main Question: How does the perception of the main character influence the teacher's choice in using multicultural picture books as teaching tools to enrich their classroom with multicultural education?

Sub-questions:

1. How does the teacher define multiculturalism?

2. Does the front cover of the contemporary multicultural picture book entice teacher use?

3. What is the teacher's perception of how contemporary multicultural picture books portray their main characters? as heroes, an individual who can solve their own problem, or a victim, one who needs someone else to solve their problem?

\section{Research Design}

In this study, the researcher (Torri) analyzed contemporary multicultural picture books, and evaluated the status of the main character based on their ability to resolve the conflict of the story on their own (hero) or with the help of someone else (victim). In each book chosen to for the study, the main character is a pre-teen, of non-American/Anglo-Saxon culture, and the picture book was published in 2000 or later, making it contemporary.

To help in the constant comparative method of data analysis, Torri used open coding to evaluate the status of the main character based on their ability to resolve the conflict of the story on their own (hero) or with the help of someone else (victim). [7] The codes included: the book cover, agency of the main character, and cultural background; along with the participant's definition of multiculturalism. From these codes, the themes that emerged and served as an impetus for our response included various cultures, reflection, added value and participation. Leading to an early conclusion that the readers of the text must take an active approach in the process of understanding the main character's agency as the story reveals the resolution, not passive.

As a teacher who had been a part of this district since 2006, I have worked with many individuals teaching grades 5-8; those individuals were asked to help me in my quest for knowledge, and eagerly obliged. However, it wasn't enough to know their thoughts, I had to compare them to mine.

Teachers were asked to complete a survey after choosing two multicultural picture books based on the cover, title and illustrations. Then, they interacted with the text and recorded their responses on the survey.

This process was completed in a familiar environment in which the teachers are used to working, Professional Learning Community room, during their conference period, planning time or afterschool. The teachers took approximately $20-30$ minutes to complete the task. There were no more than five teachers completing the task at time. Some shared books and discussed what they thought about the book, or how they could use it in their classes while they completed the survey. I gave directions, facilitated the process and observed the educators as they interacted with their chosen multicultural picture books and completed the survey.

\section{Review of the Professional Literature}

"Carefully chosen books give children opportunities to see aspects of their own identities reflected back to them, as well as opportunities to explore the lives and experiences of people and places distinctly different from their own." [1] Well-known scholars with multicultural backgrounds from around the globe, like W.E.B. DuBois, Donaldo Macedo and Paulo Freire, have spread the word about the importance of the curriculum reflecting the point of view of the learner. There are many diverse points of view representing learners in today's classrooms. Knowing how to use your point of view, and those of others around you, give you a pluralistic view. Helping the learner to not only understand themselves, but their peers.

Julia Lopez-Robertson and Mary Jade Haney wrote an article citing the work of Dr. Rudine S. Bishop stating, "... to use multicultural literature as a powerful pedagogical tool to provide children experiences with literature that serves as mirrors, windows and sliding doors." [10] The symbolic meaning is one that refers to how the reader relates to the literature; the mirror reflects their lives, the window gives them a view into the lives of others and the sliding door is an opening, allowing the reader to learn about others. Multicultural picture books are essential learning tools in classrooms; but they must be carefully chosen to be a mirror, a window, or a sliding door to inform students about various cultures in a positive way.

It is important to begin with a teacher's definition of multiculturalism. When you know how a teacher defines this aspect of education, you understand how they will approach teaching, or using multicultural literature as a teaching tool in their classroom. In an interview published online by NEA Today, conducted by Michelle Tucker, Dr. James Banks, an author and 
advocate of multicultural education, stated, “...in the minds of many science and math teachers, multicultural education was simply content integration. So I developed the 'five dimensions of multicultural education' to help educators see that content integration - say, putting content about Mexican Americans or African Americans in the curriculum - is important, but that it's only the first dimension of multicultural education, and that multicultural education has at least five dimensions." [15] With this information, it is vital to understand the teacher's knowledge base of multicultural education to observe how and what they will use to teach it.

Dr. Banks shares five dimensions of multicultural education: (1) content integration - adding information to the curriculum that showcase, or represents, individuals from various cultures; (2) knowledge construction - helping students read critically through the information present to build their knowledge base; (3) equity pedagogy - use instructional strategies so that all students, regardless of their cultural backgrounds or gender, can understand and access the information the teacher is presenting; (4) prejudice reduction - helping to learn about other cultures to decrease their negative, stereotypical, thoughts about certain groups; and (5) empowering school culture and social structure - the whole school looks at their practices, and interactions, with different groups of students and make sure that it cultivates an atmosphere of empowerment.

In this research, equity pedagogy is synonymous to culturally relevant pedagogy, which looks different in every classroom based on the students. Teachers must be aware of the students in their classrooms in order to teach them in the most effective way. Gloria LadsonBillings [9] coined the terminology culturally relevant pedagogy from her research on teachers of African American students. She followed highly qualified teachers, who all had different teaching styles. Nevertheless, the African American students were more successful in each of these situations. She determined that there are three major domains of the student's work: academic success, cultural competence, and sociopolitical consciousness. Academic success was the amount of intellectual growth that was experienced by students. Cultural competence refers to the ability to appreciate their cultures while able to gain knowledge of another culture. Sociopolitical consciousness is the ability to take learning out of the classroom and consider their out of school contexts to solve real world problems. [9] Ladson-Billings work has been sited and extended by other researchers. While she worries that some her content has lost its rigor and has become main streamed, it is still essential to understand the foundation [10].

The use of picture books is a valuable way to bring culturally relevant pedagogy to the classroom. However, the books must provide some form of cultural competence. [10], [4], [14] One positive way to do this, is to make sure the main character in the book is a hero. A character that is proud of his or her culture, and is able to work independently to solve their own problems.

Picture books are a valuable resource used in many classrooms as mentor texts and entry points into showcasing various cultures. However, when picture books are multicultural, they are a valuable tool which "helps children to identify with their own culture, exposes children to other cultures, and opens dialogue on issues regarding diversity." [5] They show language being used in a variety of ways, in addition to breaking down cultural barriers that may be present among the students from various regions of the world. As teachers present contemporary multicultural picture books in their classrooms, it is vital to have resources available that show multicultural children in a positive light solving their own problems to be the mirror, window and sliding door to new understandings about culture; their own and others.

As teachers look for reading materials for classroom instruction, they must look for stories that reflect the students in their classroom; stories that keep and spark their students' interests; all while trying to find material that the students see as relevant, so that they can make connections easily with the text. This is not an easy task. Teachers have students on different reading levels and some learning a different language. In these situations, it is imperative that students are able to read literature portraying multicultural characters in a positive manner, being successful; because they are trying to be successful too. Glazier and Seo quoted Galda's Literature-based instruction: Reshaping the curriculum saying, "The use of multicultural literature - coupled with dialogic instruction within a safe classroom context - can provide students with both a window to other cultures and a mirror reflecting their own [8]."

Another important aspect of using multicultural literature in the classroom is knowing its purpose and how we are to achieve the goal of using it as a mirror, a window or a sliding door. Dr. W. Nikola-Lisa, author of multicultural children's books, states, “...it is the belief that we must first recognize our differences, and indeed celebrate then, but ultimately we must transcend them as well - though without sacrificing our own personal and cultural sense of identity. It is in the act of 
transcendence, of finding a new, even higher level of synthesis, that our future as a multiethnic, multiracial nation lies - but we have a long way to go." [6] He agrees with Dr. Banks, that the education of our students lie in understanding and using that new knowledge to remove the barriers. That's what using multicultural literature in the classroom is all about. Allowing students to see the greatness in all of us, regardless of what we look like and where we come from; and then using that knowledge to improve our way of life.

In addition to that, teachers must be aware of their own teaching styles and biases. As an educator we set out with good intentions when adding multicultural literature to our curriculum. However, "...there is more to being a multicultural educator than using the 'right' curriculum. Being a critical, multicultural educator is as much a philosophy and way of life as it is implementation of quality instruction." [16] You have to create a learning environment that is free from adverse consequences; one that is welcoming and breeds a culture of respect and communication. In Going beyond the Book, Page states the importance of building relationships with our students, being intentional about your actions to establish trust, getting to know your students and allowing them to know you. The classroom becomes another family relationship, between teacher and student, not necessarily friendship. She also states the importance of being an advocate for your students and genuinely telling them the truth about hard topics; but most of all, have fun and enjoy your time together.

\section{Data Collection and Analysis}

I began using this pluralistic view when looking for picture books to use to model different skills with my students. I wanted the books to be easy to understand, short in length, with beautiful illustrations, but still able to relate to an adolescent student. I felt it was very important to have books with characters that reflected the students in my ESL classroom. When helping my students acquire the English language I knew they needed books with easy to understand language, illustrations that would help them understand the author's message, when the words were too difficult to comprehend. The students in my classroom were from various countries in Africa, South America and Asia; Ghana, Mexico, Puerto Rico, Honduras, El Salvador, Vietnam, and the Philippines were a few countries represented. With a classroom rich with culture, I wanted my students to see themselves reflected in the stories. To see someone their age overcoming an obstacle, despite a situation that was out of their control.

I spoke with other educators (teachers and librarians), and they were ready and willing to assistance in this research. I received lists of books, and I started researching. I wanted contemporary books, published in 2000 or later, the main characters had to be pre-teen or older, so my students could relate, and of course, multiethnicities. I ordered the books, and was really excited when I could finally put my hands on the crisp pages and truly enjoy the feel and vibrant colors showcased in them. This need in my classroom, and inquiry project for class, became the catalyst for this action research.

I ordered books of various reading levels, but paid more attention to the books I wanted to use as instructional tools. There were five picture books that caught my attention because of the beautiful illustrations, titles, and the way the main characters reflected the students in my classroom: (a) Mama's Nightingale: A Story of Immigration and Separation, (b) A Thirst for Home: A story of water across the world, (c) A Song for Cambodia, (d) Stepping stones: A refugee family's story, (e) Adrift At Sea: A Vietnamese boy's story of survival. I had to read them and understand them more.

I began with A Thirst for Home. This book grabbed my attention because I saw a little girl on the cover who looked like me. I empathized with her because of the title. I understand that water is essential to life, and thirsting for it... was unknown to me. I truly enjoyed the play on words. As I read the story I was enticed by the beautiful colors in the illustrations to continue reading the story. But, by the end of the story, I was mad because the little girl, Alemitu, needed someone else to help her solve her problem. I wondered, will I always need someone to help me, or can I solve my own problems and help others in the process.

I realized that to understand this issue, I had to ask the right questions. But the questions had to include what I saw, the meaning I created while reading, and how the story made me feel.

In order to address the sub-questions of the study, it is important to identify the data required to answer the questions, ways the data will be analyzed, and how the findings will be presented. I analyzed the teachers' responses to being a hero or victim, and then summarized the results of the survey (see Table 1). In this section, data collection and analysis procedures are presented for each sub-question.

\section{How does the teacher define multiculturalism?}


This question was answered by collecting information from the participants directly through a survey item. Participants were asked to write their definition of multiculturalism, after they provided demographic information, and before they interacted with their chosen multicultural picture books. This provided insight into how the teacher views multiculturalism. The researcher collected all data and synthesized their written words into one definition.

Only four of the six participants provided their definition of multiculturalism on the survey. All of the responses included "variety of cultures", or "more than one culture", however their intents were all different. When asked why a definition was not provided, the two participants stated they couldn't find the right words to explain what they were thinking at the time.

I looked at the verbs, and other words, used to describe what would be done with the multiple cultures; and the participants reported: reflection, exposure and familiarity, added value and participation. I agreed with the collected definition of all the participants, because it reflected my own thinking and that of Dr. Banks. I believe multiculturalism is the ability to add value to your life by learning from other cultures through exposure, participation in cultural traditions/rituals, and then reflecting on those experiences to enhance your own way of living.

\section{Does the front cover of the multicultural picture book entice teacher use?}

This question was answered by collecting information from the participants directly through the survey item; it stated, "Based on the cover of the book, would you use it to teach a lesson on multiculturalism? Please explain why." The participants have reported their definition of multiculturalism, but have not interacted with the text. First, the participants chose two, out five books, and then used them to complete the rest of the survey. They had only seen the cover of the books, and many of the participants stated that they had never seen or heard of these books before. I am definitely enticed by pictures. I have always enjoyed the different hues, resolution, or saturation of colors. When someone else presents a visual to me from their perspective, an illustrator, I always try to put myself in their shoes and question why they chose to present the object in that manner. I felt as if the teachers did the same thing. Their insights and the discourse that evolved from only looking at the cover, validated the value of the book's title and illustrations on the cover. It was the cover that made the teacher pick the book up, but only if it reflected an experience they had in life.

The five books were: (a) Mama's Nightingale: A Story of Immigration and Separation, (b) A Thirst for Home: A story of water across the world, (c) A Song for Cambodia, (d) Stepping stones: A refugee family's story, (e) Adrift At Sea: A Vietnamese boy's story of survival.

Table 1. Teacher survey results on contemporary multicultural picture books

\begin{tabular}{|c|c|c|c|c|c|c|c|c|c|c|c|c|}
\hline Participant & \multicolumn{2}{|r|}{$\# 1$} & \multicolumn{2}{|c|}{$\# 2$} & \multicolumn{2}{|c|}{$\# 3$} & \multicolumn{2}{|c|}{$\# 4$} & \multicolumn{2}{|r|}{$\# 5$} & \multicolumn{2}{|c|}{$\# 6$} \\
\hline Title & $\mathrm{a}$ & $\mathrm{e}$ & $\mathrm{e}$ & $\mathrm{b}$ & $\mathrm{d}$ & $\mathrm{E}$ & $\mathrm{B}$ & $\mathrm{a}$ & $\mathrm{d}$ & $\mathrm{b}$ & $\mathrm{e}$ & $\mathrm{c}$ \\
\hline Cover & $\mathrm{Y}$ & $\mathrm{N}$ & $\mathrm{Y}$ & $\mathrm{Y}$ & $\mathrm{Y}$ & $\mathrm{Y}$ & $\mathrm{N}$ & $\mathrm{Y}$ & $\mathrm{Y}$ & $Y$ & $\mathrm{Y}$ & $Y$ \\
\hline $\begin{array}{l}\text { Hero or } \\
\text { Victim }\end{array}$ & $\mathrm{H}$ & $\mathrm{V}$ & $\mathrm{H}$ & $\mathrm{H}$ & $\mathrm{H}$ & $\mathrm{H}$ & $\mathrm{V}$ & $\mathrm{H}$ & $\mathrm{V}$ & $\mathrm{n} / \mathrm{a}$ & $\begin{array}{l}\mathrm{H} \\
\mathrm{V} \\
\end{array}$ & $\mathrm{n} / \mathrm{r}$ \\
\hline Other & $\mathrm{n} / \mathrm{a}$ & $\mathrm{n} / \mathrm{a}$ & $\mathrm{n} / \mathrm{a}$ & $\mathrm{n} / \mathrm{a}$ & $\mathrm{n} / \mathrm{a}$ & $\mathrm{n} / \mathrm{a}$ & $\mathrm{n} / \mathrm{a}$ & $\mathrm{n} / \mathrm{a}$ & $\mathrm{n} / \mathrm{a}$ & Survivor & $\mathrm{n} / \mathrm{a}$ & $\mathrm{n} / \mathrm{a}$ \\
\hline $\begin{array}{l}\text { Use to } \\
\text { teach } \\
\text { lesson }\end{array}$ & $\mathrm{Y}$ & $\begin{array}{c}\text { Maybe/ } \\
\text { N }\end{array}$ & $\mathrm{Y}$ & $\mathrm{Y}$ & $\mathrm{Y}$ & $\mathrm{n} / \mathrm{r}$ & $\mathrm{Y}$ & $\mathrm{Y}$ & $\mathrm{Y}$ & $\mathrm{Y}$ & $\mathrm{Y}$ & $\mathrm{n} / \mathrm{r}$ \\
\hline
\end{tabular}

Based on the cover of the books presented, Adrift at Sea: A Vietnamese boy's story of survival was chosen most frequently by the participants $(1,2,3 \& 6)$, four out of twelve times; and one participant would not have used it as a teaching tool. The participant (1) stated that the cover didn't seem to represent a specific culture, just an idea of being lost at sea. They also stated that it would need supporting texts to help students relate to it, like currents events (people trying to cross the border in Texas). Based on this comment alone, there is a correlation with Dr. Bank's five dimensions (content integration \& knowledge construction).

The next book chosen based on its cover frequently was A Thirst for Home: A story of water across the world was chosen three (participants 2, 4, \& 5) out of twelve times. One participant (4), based on the cover, would not use it to teach with because it only presented one culture. However, the participant did state that after 
reading the text, they would use it because it showed similarities and differences between two cultures.

Two books, Mama's Nightingale: A Story of Immigration and Separation and Stepping stones: A refugee family's story were chosen twice (participants $4 \& 1 ; 5 \& 3$ ) out of twelve, and both participants would use this text as a teaching tool for multicultural education based on the cover and the content.

One book, A Song for Cambodia, was chosen once based on its cover. The participant (6) stated they had hoped for a poem or song that could be incorporated into the lesson. No other information was provided.

3. What is the teacher's perception of how contemporary multicultural picture books portray their main characters? as heroes, an individual who can solve their own problem, or a victim, one who needs someone else to solve their problem?

This question was answered by collecting information from the participant directly through a survey item. The participant read the book and then provided their response to, "...tell me if the main character is a hero (solves their own problem) or a victim (needs help solving their problem). Explain why you think this way."

The participants perceived the main characters in the picture books seven out of twelve times as a hero; all of them responded by discussing how the main character overcame a struggle or the circumstances they were put in. Three times the teachers perceived the main character as a victim, reporting things just kept happening to them that were beyond their control; they couldn't act to overcome the struggle themselves, but needed someone else to help them. One participant stated the main character was both (a victim and a hero) in Adrift At Sea: A Vietnamese boy's story of survival; the participant gave evidence from the story to explain their thinking (put in a camp against his will and being help by supporting his fellow kids). Another participant suggested a new category, survivor, for the main character in A Thirst for Home: A story of water across the world, stating there is no agency (Eva does what she is told. If there is a hero, it is her Emaye. She made a brave sacrifice).

\section{Discussions}

In comparison with Dr. Bank's Five Dimensions of Multicultural Education, all of the participants together would have fulfilled his dimensions. This demonstrates the power of interconnectedness in education. Alone, one participant understood implementing one dimension, but together they all covered the true meaning of implementing multicultural education.

When observing the participants fill out their survey and interact with the picture books, different conversations were sparked about the text and how they could use them in their classrooms. The participants engaged in discourse about the different learning standards the texts aligned with and how they could help the students write about different topics; using the texts as springboards into an expository writing assignment about overcoming obstacles. This observation lead to the conclusion that teachers need time to have discourse and plan together, so that they are able to share ideas and provide their students with the whole experience of multicultural education, not just one dimension.

Many of the participants reported that the illustrations, had "beautiful colors and depictions of culture", along with the titles, and word choice, drew them to the book. However, one participant pointed out "the symbolism was ever present on the cover"; while two others thought it related to the current events and could be a catalyst for conversation in their classrooms. These participants were seeking to create an environment with open conversation and help students think critically about things that are relevant to them. Again, implementing Dr. Bank's Five Dimensions of Multicultural Education, and enriching the educational journey of our students.

Many of the participants expressed interest in using the books in their classrooms as a catalyst for writing assignments. Other suggestions would be to use as a catalyst for student-led community service projects, or a research problem allowing the students to inquire about the time period in which each story occurred. Having contemporary multicultural literature on campuses can lead to culturally relevant and enriched learning experiences in the classroom.

This study was conducted during the school day and after school when most teachers are stressed for time. More information could have been gathered in a focus group after completing the survey, to gain insight through discourse, and to share more ideas that could enrich these classrooms with multicultural education.

\section{Reflections}

\section{Torri's Reflection}

As I read each book, I tried to put myself in the main character's shoes, expressing empathy, even if I had never gone through what the story told me. However, I understood what it was like to struggle, or to overcome situations that were out of my control because of life experiences and simple history lessons from school. After reading all five books, I learned that it is very important to understand the historical and cultural setting before I made a judgement about the main character's agency as the story reveals its resolution. And that is an essential learning standard in Texas for reading. 
Finding contemporary multicultural picture books that represent youth and adolescents was not an easy task. Many books being published are for younger people, and many are not a true reflection of our population. We need more books that represent students in our classrooms. More literature that allows them to see themselves as successful humans embracing their culture, while trying to understand other, and thrive together. Learning about other cultures isn't about devaluing others to put yourself on top. It's about embracing our differences and learning how we are similar. This is why we learn history from around the world. This is why we embrace the knowledge from mathematicians and scientists from around the world. This is why we want to help our students become global citizens, so that all may survive. Not just me, but we.

After completing this research, I will definitely continue to look for contemporary multicultural picture books that show the main characters as heroes, exposing my students, and others, to the rich cultural perspectives through literature. But I many even write a book and add to the list myself.

\section{Additional Books with Multicultural Heroes}

Yo Soy Muslim: A Father's Letter to his Daughter By Mark Gonzalas

Mehrdokht Amini (Illustrator)

A Muslim and Latino poet Mark Gonzales has a touching lyrical poem to his daughter helping her to find the joy in life.

Garvey's Choice

By Nikki Grimes

Not a picture book, but a short collection of poems about this one character, Garvey. Despite many challenges (overweight, middle school, wants father's attention though he isn't an athlete) he is considered the hero once he comes into himself.

Ada's Violin: The Story of the Recycled Orchestra of Paraguay

By Susan Hood

While the main character is the teacher, band director, the students are all middle school children who learn to play music using recycled materials. They had to work together as a community to make this band happen.

\section{Last Stop on Market Street}

By Matt De La Pena

About a young African American boy name CJ who learns to appreciate the everyday things when he is on a bus ride with his grandmother.

Stormy Seas: Stories of Young Boat Refugees
By Mary Beth Leatherdale Actual stories from young refugees from different times.

\section{Conclusions}

Words and pictures are powerful tools in gaining someone's attention. This is true for a book, but it is also true for multicultural education. When teachers looked at the cover of the books, it made them feel a certain way, it provoked thought, connected them to current events; it opened a window into a new thought process that was not there before. And once the teacher opened the book and read the pages, a new understanding of how to teach the lesson begin to form. Then the teacher decided if that book would open a door for their students?

What door shall I open? How do I get my students to think about this topic, and decide on their own a new way to approach this person, this culture? The way a character is portrayed in a book influences how the teacher gives instruction and the learning that will come from it. Whether the main character is seen as a victim or a hero changes the learning objective, not the use of the tool. However, it does impact the learning environment and how students feel. These are things the teacher must keep in mind when choosing tools to enrich their classrooms with multicultural education.

\section{References}

[1] Baldwin, K. (2018, May). The Power of Using International Picture Books with Young Children. Young Children, 74-80.

[2] Banks, J. A. (2007). Educating citizens in a multicultural society. New York: Teachers College Press.

[3] 2010 Census. (2010). Retrieved from http://www.dfwinte rnational.org/resource_center/2010Report.pdf

[4] Chi-Hung Leung \& Ming-Tak Hue (2017) Understanding and enhancing multicultural teaching in preschool, Early Child Development and Care, 187:12,20022014, DOI: $10.1080 / 03004430.2016 .1203308$

[5] Colby, Susan A., and Anna F. Lyon. "Heightening Awareness about the Importance of using Multicultural Literature." Multicultural Education 11.3 (2004): 248. ProQuest. 10 Nov. 2018

[6] Fox, D. L., \& Short, K. G. (2003). Stories matter: The complexity of cultural authenticity in children's literature. Urbana, IL: National Council of Teachers of English.

[7] Glaser, Barney. (1978). Theoretical sensitivity: advances of grounded theory. Mill Valley, CA: Sociology Press. 
[8] Glazier, Jocelyn, and Jung-A Seo. "Multicultural Literature and Discussion as Mirror and Window?" Journal of Adolescent \& Adult Literacy 48.8 (2005): 686700. ProQuest. 10 Nov. 2018

[9] Ladson-Billings, G. (1994). The Dreamkeepers. San Fransico, CA: Josey Bass Publications.

[10] Ladson-Billings, G. (2014). Culturally relevant pedagogy 2.0: A.k.a. the remix. Harvard

Educational Review, 84(1), 74-84,135. Retrieved from https://login.proxy.tamuc.edu/login?url=https://searchproquestcom.proxy.tamuc.edu/docview/1511014412?accou ntid=7083

[11] Lee, A., \& Danby, S. (Eds.). (2012). Reshaping doctoral education: International approaches and pedagogies. Retrieved from https://ebookcentral-proquestcom.proxy.tamuc.edu

[12] Lopez-Robertson, J., \& Haney, M. J. (2017). Their Eyes Sparkled: Building Classroom Community Through Multicultural Literature. Journal of Children's Literature, 43(1), 48-54.

[13] Lovitts, B. (2008) The Transition to Independent Research: Who Makes It, Who Doesn't, and Why, The Journal of Higher Education, 79:3, 296-325, DOI: 10.1080/00221546.2008.11772100

[14] Lowenstein, K. L. (2009). The work of multicultural teacher education: Reconceptualizing white

teacher candidates as learners. Review of Educational Research, 79(1), 163-196. Retrieved from https://login.proxy.tamuc.edu/login?url=https://searchproquestcom.proxy.tamuc.edu/docview/214135927?account $\mathrm{id}=7083$

[15] Multiculturalism's Five Dimensions [Interview by M. Tucker]. (1998, September). NEA Today Online. Retrieved November 17, 2018, from https://www.learner.org/workshop s/socialstudies/pdf/session3/3.Multiculturalism.pdf.

[16] Page, Michelle L. "Going Beyond the Book: A Multicultural Educator in the English Language Arts Classroom." Voices from the Middle 12.1 (2004): 815. ProQuest. 10 Nov. 2018

[17] Sims Bishop, R. (1990). Mirrors, Windows, and Sliding Glass Doors. Perspectives: Choosing and Using Books for the Classroom, 6(3), summer.

[18] Suh, Yonghee, and KaaVonia Hinton. "Mirroring Ourselves: Teacher Educators of Color Reading Multicultural Texts." Issues in Teacher Education 24.2 (2015): 23-42. ProQuest. 10 Nov. 2018

[19] Weiss-Armush, A.M. (2010) DFW's International 2010 Progress Report Executive Summary. Retrieved from http://www.dfwinternational.org/resource_center/2010Repo rt.pdf
[20] Yoo-Lee, E., Fowler, L., Adkins, D., Kim, K., \& Davis, H. N. (2014). Evaluating Cultural Authenticity in Multicultural Picture Books: A Collaborative Analysis for Diversity Education. The Library Quarterly,84(3), 324-347. doi:10.1086/676490

[21] Danticat, E., \& Staub, L. (2015). Mama's Nightingale: A Story of Immigration and Separation. New York, NY: Dial Book for Young Readers.

[22] De La Pena, M. (2015). Last stop on market street. New York, NY: Penguin.

[23] Grimes, N. (2016). Garvey's choice. New York, NY: Wordsong.

[24] Gonzalas, M. (2017). Yo soy Muslim: A father's letter to his daughter. New York, NY: Simon and

Schuster.

[25] Hood, S. (2016). Ada's violin: The story of the recycled orchestra of Paraguay. New York, NY:

Simon and Schuster.

[26] Ieronimo, C., \& Velasquez, E. (2014). A Thirst for Home: A story of water across the world. New York: Walker Books for Young Readers, an imprint of Bloomsbury.

[27] Leatherdale, M.B. (2017). Stormy seas: Stories of young refugees. Toronto, Canada: Annick

Press.

[28] Lord, M., \& Arihara, S. (2015). A Song for Cambodia. N2w York, NY: Lee \& Low Books.

[29] Ruurs, M., Badr, N. A., \& Raheem, F. (2016). Stepping stones: A refugee family's story. Custer, WA: Orca Book.

[30] Skrypuch, M. F., Deines, B., \& Ho, T. (2016). Adrift At Sea: A Vietnamese boy's story of survival. Toronto, Ontario, Canada: Pajama Press. 